\title{
MUSIC AS A VEHICLE FOR CONQUERING SPACE IN JESUIT NYSA AND ITS NEIGHBOURHOODS
}

\author{
ToMAsz JEŻ
}

Tomasz Jeż; Uniwersytet Warszawski, Krakowskie Przedmieście 32, 00-325 Warszawa; e-mail: tomasz.jez@uw.edu.pl

\section{Abstract}

The presence of the Jesuits in the artistic culture of the early modern era has been defined as a mission and an accommodation to the "people, times, and places". Music, considered as a spatial phenomenon, had an important function in this mission, mostly due to its rhetorical qualities. Based on the example of Nysa/Neisse, the paper's author shows how music influenced the social space of the local community and affected their sense of security and identity describing the way space was conquered by music reshaping the town's microcosm and its neighbourhoods.

Keywords: Jesuits, Nysa/Neisse, soundscape, social impact

\section{Pastoral strategies of Jesuits}

The Jesuit presence in artistic culture can be defined as a mission and an accommodation. ${ }^{1}$ To ensure the widest possible reception of the preached content, the language and the object of the mission to the "people, times, and places" had to be accommodated in accordance with the Jesuit constitutions. ${ }^{2}$ All three subjects are crucial to understand the Jesuit modus operandi, which is also revealed in the musical culture.

1 HARWELl, Celenza Anna - DELDONNA, Anthony R. (ed.): Music as Cultural Mission. Explorations of Jesuit Practices in Italy and North America. Philadelphia : Saint Joseph's University Press, 2014.

2 Constitutiones Societatis Iesu a Congregatione Generali XXXIV annotatae et Normae complementariae ab aedem Congregatione approbatae. Romae : Apud curiam praepositi generalis Societatis Iesu, 1995, No. 455, p. 170. 
Music can be treated both as an object and a language, which has led to its effectiveness not only in overseas missions, but also pastoral activity in the "Indias around here" of various places in Europe. ${ }^{3}$

The constitutional recommendation of adjusting musical practice to people brought significant social change. Jesuits were capable of forming a community from any anonymous social group using an appropriate repertoire. Looking for efficacious forms of religious instruction, they supported natural cofigurative strategies, which allowed a group to become self-directed, such as lay (school or citizens) congregations. Music served in the identification and affirmation of these communities, and confirmed its social structure and prerogatives. ${ }^{4}$ Focusing on the instruction of boys gathered in processions, and church, school or musical ensembles, Jesuit missionaries also used a prefigurative mode of culture, ${ }^{5}$ which ensured their victory in the confessional confrontation of the era.

The music of the Jesuit mission in culture also transformed time as perceived by communities. Their social order was reshaped by conscious strategies of recurrence and periodicity, which supported and regulated the rhythm of the community life. Elements of this regularity may be found in the Jesuit musical repertoire: the litany, the rondo, the sequential, stanzaic and verse forms. But the community's sacred time was also measured with recurrent performances of the Salve Regina, with meditationes for consecutive Sundays of Lent, with quarterly Requiem masses and annual spectacles pro renovatione studiorum. A natural pretext for this regulation was the regularity of the liturgical cycle, broadened by the Jesuits so as to include new, paraliturgical elements, making use of the local traditions.

But another dimension of the pastoral activity is the space in which it takes place. The Jesuit mission brought deep changes to the arrangement of space, both in the centres of towns as well as neighbourhoods. The newly erected churches, colleges, gymnasiums, boarding schools, and seminaries transformed the architectural design of cities. ${ }^{6}$ Most of these buildings were venues for music, as well as the town squares, streets and bridges, which hosted regular paraliturgical performances. The music played during the church services, school theatrical spectacles, processions and pilgrimages annexed public space, highlighting the social change. It was not only an expression of the community's faith, but also served for its propagation: both in the towns such as on the routes leading to the holy shrines, and the borders of the community's area.

3 DOMPNIER, Bernard: Les cantiques dans la pastorale missionaire en France au XVIIe siècle. In: NANNI, Stefania (ed.). La musica dei semplici. L'altra controriforma. Roma : Viella, 2012, pp. 72-106.

4 JEŻ, Tomasz: The Musical Culture of the Jesuits in Silesia and the Kłodzko County (1581-1776). (=Eastern European Studies in Musicology, 11.) Berlin; Bern; Bruxelles; New York; Oxford; Warszawa; Wien : Peter Lang, 2019, pp. 327-338.

5 MEAD, Margaret: Culture and Commitment. A Study of a Generation Gap, Garden City, NY : Natural History Press New York, 1970, pp. 51-76.

6 PASZENDA, Jerzy: Budowle jezuickie w Polsce XVI-XVIII w., Vols. I-IV. Kraków : The Faculty of Philosophy of the Society of Jesus; Wydawnictwo WAM, 1999-2010. 


\section{Music as a spatial phenomenon}

Music played an important function in the Jesuit mission due to its rhetorical qualities. This rich presence in culture resulted not only from its close relationship to the language, but also from the immanent spatial characteristics of this art. If we wish to say anything about music, we cannot isolate it from the space in which it is played. Taking account of the social function of music, it must be studied in its social environment, which includes the space for its performance. Musical topography can be considered a very interesting methodological perspective. ${ }^{7}$ But the spatial quality of music is closely related to its rhetorical features, and both are clearly visible in the context of a mission. Given these circumstances, I examine how music was used to conquer space, based on an example of the Silesian town of Nysa at the time of the Counter-Reformation.

This battle for souls took place initially in the space of the church: in our case the baroque church designed by Andrea de Quadro and dedicated to the Assumption of Holy Virgin Mary. ${ }^{8}$ The square nave of the church was popular in Jesuit circles mostly for its acoustic qualities, which was put to good use not only by preachers, but also musicians, singing in choir or both the galleries, covered with frescoes by Karl Dankwart. ${ }^{9}$ This cycle of paintings corresponded with the analogous cyclic music forms performed in the church: the Litanies and Marian antiphons, which in many Jesuit churches of this area are also represented in iconographic form. ${ }^{10}$ Looking around the church, the participant in a liturgy could contemplate the same cultural texts in the musical works which, together with the graphic form, encouraged them to embark on their own journey of faith.

Even more persuasive were the paraliturgical events connected with Christmas and Holy Week, which combined prayer with stage action and music. Praesepia and sepolcri embodied the ideal of Ignatian spirituality, expressed in the compositio loci method. ${ }^{11}$ Both events could be considered as counterparts of Spiritual Exercises, even though the representation of the sacred topic here is only imagined and not real. The space for this event was defined not only by the actors and scenography installed in the chapel, but also by the music, which penetrated all of the space of the church. Other sacred places of the church found their counterpart in the space of the school: i.e. the

Seen in recent musicological studies such as: PIÉJUS, Anne: Musique et dévotion à Rome à la fin de la Renaissance: Les Laudes de l'Oratoire. Turnhout : Brepols, 2013; CAVICCHI, Camilla - COLIN, Marie-Alexis - VENDRIX, Philippe (eds.): La musique en Picardie du XIVe au XVIIe siècle. Turnhout : Brepols, 2012; RODRÍGUEZ-GARCÍA, Esperanza - FILIPPI, Daniele V. (eds.): Mapping the Motet in the Post-Tridentine Era. Abingdon; New York : Routledge, 2018.

8 KALINOWSKI, Konstanty: Kościół jezuicki w Nysie. In: Opolski Rocznik Muzealny, Vol. 4, 1970, pp. 391-439.

$9 \quad$ KOZIEŁ, Andrzej: Szwed i jezuici. Karl Dankwart i jego nieznane prace malarskie dla nyskich i kłodzkich jezuitów. In: Po obu stronach Bałtyku. Wzajemne relacje między Skandynawia a Europq Środkowa, Vol. I. Wrocław : Wydawnictwo Via Nova, 2006, pp. 265-276.

10 KLAHR, Michael: O Clemens, Assumption of the Holy Virgin Mary Church; KUBEN, Johann: Salus Infirmorum, Exaltation of the Holy Cross Church in Brzeg.

11 FLEMING, David L. (ed.): The Spiritual Exercises of Saint Ignatius: A literal translation and a contemporary reading. St Louis : Institute of Jesuit Studies, 1989, No. 112, p. 74. 
relics of Saint Romanus ${ }^{12}$ corresponded to drama performed in the gymnasium devoted to the life of this martyr. ${ }^{13}$

In honour of the saints, whose relics are kept in the Jesuit church of Nysa, new songs were composed. Most of them used familiar melodies and were written in German, which served as propaganda in the confessional struggle. ${ }^{14}$ The new songs could be sung by all the Catholic population of the town thanks to the pamphlet editions, distributed on the occasion of the translation of relics from the Roman catacombs. ${ }^{15}$ In this way, the new song text not only unified the whole space of the city, but also gave symbolical justification to the "Silesian Rome" nickname, given to Nysa, and not only for this reason.

\section{The town microcosm}

If we compare the town surrounded by its ribbon of walls to a loudspeaker, its streets can be thought of as a kind of diaphragm, emitting sound in its space. Its vibration is due to the "magnetic field" produced by the various music institutions: churches, schools and official buildings. In its day, Nysa was a centre of particular importance to the Jesuit missions in Silesia. ${ }^{16}$ It was the residence of the bishops of Wrocław, and a diocesan seminary operated here from 1575 and it was the first town of Silesia with a stable Jesuit residence.

Jesuits settled in Nysa thanks to Bishop Karl Habsburg (1608-1624), who completed a Jesuit education and was the founder of Collegium Carolinum. ${ }^{17}$ Karl was a renowned patron of the arts: the musicians who worked in his music chapel included Giovanni Valentini, Stefano Bernardi and Antonio Cifra, previously chapel master of the Collegium Germanicum and the Santa Casa sanctuary in Loreto. ${ }^{18}$ The next bishop,

12 SCHMIDL, Johann: Historiae Societatis Jesu provinciae Bohemiae. Prague : Academic Printhouse [1759], Vol. IV/2, p. 933.

13 S. Romanus Martyr pia tragedia, ad serenissimum... Nysa : Johann Schubart, 1653. Wrocław, Biblioteka Uniwersytecka, Oddział Starych Druków, 356658.

14 JEŻ, Tomasz: The Musical Repertory between the Confessions. Re-Catholicising Strategies in the Songbook of Johannes Schubart from Neisse (1625). In: Musicology Today, Vol. 10, 2013, pp. 19-36.

15 Lobgesang dem Herzlichen Sissinio Römischen Diacono und Martyri. Als er von der Stadt Rom erhaben, inn deß Collegij der Societet Jesu Kirch zu Neyß Transferiert Anno 1636. In der zu dessen Heyligen Ehr angestellten Procession Dedicirt und gesungen. Im Thon: Frew dich du Himmel königin... Neisse : Johann Schubart, 1636; Ein Newer Christlicher Lobgesang, Bey Feyerlich-angestelter Translation der Heyligen Jungfrawen vnd Marterin Secundae zu Glatz newlich auffgesetzet 1641 Im Thon, vnd versetzten Texts imitation Allein Gott in der Höh sey Ehr, \& c... Neisse : Johann Schubart, 1641.

16 DOLA, Kazimierz: Jezuici w Nysie. Kolegium i gimnazjum (zw. Carolinum) 1622-1776. Opole : Wydawnictwo Świętego Krzyża, 2019.

17 KROESS, Alois: Geschichte der böhmischen Provinz der Gesellschaft Jesu. Nach den Quellen bearbeitet, Vol. 3: Die Zeit von 1665 bis zur Aufhebung der Gesellschaft Jesu im Jahre 1773. Neu bearbeitet und ergänzt von P. Karl Forster SJ. Praha : Česká provincie Tovaryšstva Ježíšova; Olomouc : Refugium Velehrad-Roma, 2012, pp. 370-371.

18 FEDERHOFFER, Helmuth: Musikpflege und Musiker am Grazer Habsburgerhof der Erzherzöge Karl und Ferdinand von Innerösterreich (1564-1619). Mainz : B. Schott’s Söhne, 1967, pp. 195-198; 
Karl Ferdinand Vasa (1625-1655), hired in his ensemble Marcin Mielczewski ${ }^{19}$ and expanded the foundations established by his predecessor: from the funds he left to the Jesuits, they constructed buildings for the boarding school, college and church. The dynamic expansion of the Jesuits in Nysa was also supported by Bishop Leopold Wilhelm Habsburg (1656-1662), who recruited musicians for his ensemble from the Basilica of Saint Mark in Venice, via the intermediary of the Jesuit Giacinto Cornacchioli. ${ }^{20}$

Apart from the private music ensemble of Nysa bishops, from 1630 its activity started Seminarium Sanctae Annae, which was established thanks to a subvention from Anna Gebauer. ${ }^{21}$ This boarding school dedicated to teaching music to boys, was ruled by the Jesuit fathers, some of whom were composers, ${ }^{22}$ others - such as Christoph Keller (1595-1655) and Felix Kadlinsky (1613-1675) - were translators of song texts, published in the prints of Nysa sodalities, led by the same Jesuits. ${ }^{23}$ The songs were sung during processions and pilgrimages both within the town and extra urbem, and were played by the boarding school musicians, who performed appropriate litanies at climactic moments in those processions. ${ }^{24}$ The alumni of convictus also performed

FEDERHOFFER, Helmuth: Graz Court Musicians and their Contributions to the "Parnassus Musicus Ferdinandeus (1615)”. In: Musica Disciplina, Vol. 9, 1955, pp. 178-192; PRZYBYSZEWSKA-JARMIŃSKA, Barbara: Starania biskupa wrocławskiego Karola Habsburga o pozyskanie włoskich śpiewaków (1621-1622). In: Res Facta Nova, Vol. 6 (15), 2003, pp. 129-132.

19 PRZYBYSZEWSKA-JARMIŃSKA, Barbara: Marcin Mielczewski and Music under the Patronage of the Polish Vasas. (=Eastern European Studies in Musicology, 3.) Berlin; Bern; Bruxelles; New York; Oxford; Warszawa; Wien : Peter Lang 2011, pp. 8, 202.

20 SAUNDERS, Steven: Cross, Sword, and Lyre: Sacred Music at the Imperial Court of Ferdinand II of Habsburg (1619-1637). Oxford : Clarendon Press, 1995, p. 7.

21 SCHMIDL, Ref. 12. Vol. III, pp. 1069-1070.

22 The music prefects of the Nysa convictus included composers, among them Martin Obersbach (1615-1689), who composed the concerto Nativitas est hodie Mariae (Kroměříž, Collegiate Church of St Maurice A 257/1). Music was also composed by Christoph Todtfeller (1624-1678), who published Geistliches Hirten-Lied von dem verlohrnen Schäflein, appended to a collection of his Passiontide sermons (Das Verlohrne Schaaf, Das ist: Fasten=Exhorationes, In welchen eine Sündhaffte Seel, so gleich einem jrrendem Schäfflein, durch allerhand Müssbrauch der Creaturen, von deren Schöpffer abgewichen... Eine Lob-Predig von dem Heiligen Patriarchen IGNATIO, Stiefftern der Societät IESU, In welcher Hochgedachter Heiliger Vatter einem Frommen Wolff verglichen wird, Geprediget In dem Oratorio deß Kayserlichen Collegii Societate IESU, in der Stadt Bresslaw: Von dem Ehrwürdigen P. Christophoro Todtfeller, der Soc: Jesu Priestern, und H. Schrifft Doctore... Prague : Academic Printhouse, 1677.

23 Myrrhen-Büschel Oder Betrachtungen und Gebet Von der Heyligen Wunden, und Leyden Christi. $\mathrm{Zu}$ beförderung Der Andacht Gegen dem Allerheiligen Leyden unsers Herrn Jesu Christi. Allen Sodalen und Liebhabern JESU deß Gekreuzigten. Zu Nutz. Gezogen auß dem Lateinischen Myrrhen Büschel deß Wohl Ehrwürdingen P. Vincentij Caraffa jetzund Generals der Societet Jesu, und Anders Andächtigen Authoren. Cum licentia superiorum. Gedruckt In der Fürstlichen und Bischöfflichen Residentzstadt Neyss bey Joann Schubart M.D.C.XLVII.

24 Repertoire of this type can also be found in other Nysa prints by Schubart, including Catholische Kirchengesänge und geistlich Lieder, mit sondern fleiss zusammen getragen von newem, so durch das gantze Jahr auff alle H. Festtage, bey den Creutzgängen, vnd zu anderen Zeitten, sehr nützlich zugebrachen... Gedruckt zu Neyß, bey Johann Schubart, Anno 1625; Geistlicher Paradeiß Vogel Der Catholischen Deutschen Daß ist: Außerlößene Catholische Gesänge, auß gar vielen Alt vnd Newen Catholischen Gesängbüchern, auff alle Zeiten deß gantzen Jahrs, zu Hauß, in Kirchen, bey den Processionen und Wallfahrten nutzlich zugebrauchen... Neisse : Ignaz K. Schubart, 1663. See 
music at the court of Bishop Charles Ferdinand who, it is said, used to listen to the student ensemble more eagerly than he did to his private orchestra. ${ }^{25}$

The prime responsibility of the Nysa convictores, however, was to provide musical settings for liturgies at the Church of the Assumption. In addition to Sunday Masses, they were obliged to sing and play the Saturday Litanies of Loreto ${ }^{26}$ the Tuesday hymn to Saint Aloysius Gonzaga, ${ }^{27}$ litanies and Vespers during the novenas in honour of Saint Francis Xavier and Saint John Francis Regis, ${ }^{28}$ as well as annual ceremonies dedicated to Saint Anne ${ }^{29}$ and memorial masses for a departed donor's soul. ${ }^{30}$ These events occurred very frequently, so the presence of music in Jesuit churches was almost continuous.

\section{Social space of community}

Musical performances also filled the social space of other communities. The sodalities of Assumption, of Annunciation, of Purification, of Visitation, of Our Lady of Sorrows, of the Mortal Agony of Christ, and of Saint Isidore used to meet every month for their liturgies and congregations. Their chapels resounded with various kind of music in a cyclic way, which made the church almost pulsate like a music instrument. At Lent, some of the communities met even more often, i.e. the Annunciation sodality performed its meditationes quadragesimales every Lent Sunday. ${ }^{31}$

Apart from time spent in the chapels intended for the inner circle of sodality members, on some days in the year they participated in street celebrations, which were an opportunity to manifest their faith in the public space of the city. This experience strengthened the identification of the participants with the community, which was a spatial representation of the sacrum. But the procession also played an important social role: its order reflected the diversity of the groups, together forming the universe of the town residents. The event was frequently accompanied by music, performed not only by vocalists, but also by loud brass instruments and timpani, well suited to outdoor festivities. ${ }^{32}$

The music sung during these processions reflected elements of spiritual life: integrity, unity, and beauty. Each of its groups had its own repertoire which manifested itself in different ways during the procession. The music played by Jesuits referred both to

JEŻ, Tomasz: Jezuicka tradycja kancjonałowa w nyskiej oficynie Johanna Schubarta. In: HAŁUB, Marek - MAŃKO-MATYSIAK, Anna (eds.): Śląska Republika Uczonych, Vol. 5, Wrocław : Oficyna Wydawnicza ATUT; Wrocławskie Wydawnictwo Oświatowe, 2012, pp. 149-171.

25 SCHMIDL, Ref. 12, Vol. IV/2 [1759], p. 622.

26 Archivum Romanum Societatis Iesu (hereafter: ARSI) Boh. 112: Litterae Annuae Provinciae Bohemiae (1700), p. 5.

27 HOFFMANN, Hermann: Der Anfang der schlesischen Jesuitenprovinz. In: Zeitschrift des Vereins für Geschichte (und Altertum) Schlesiens, Vol. 62, 1928, pp. 147-171, here: pp. 159-160.

28 ARSI Boh. 129: Litterae Annuae Provinciae Bohemiae (1716), pp. 159-160.

29 ARSI Boh. 126: Litterae Annuae Provinciae Bohemiae (1713), p. 102.

30 ARSI Boh. 120: Litterae Annuae Provinciae Bohemiae (1708), p. 141.

31 ARSI Boh. 102: Litterae Annuae Provinciae Bohemiae (1679), p. 555.

32 SCHMIDL, Ref. 12, Vol. III, p. 695. 
the tradition of Latin repertoire and songs. ${ }^{33}$ The diversity of the repertoire performed on such occasions reflected the universal character of these festivities. In addition to plainchant, other sung repertoire included hymns, litanies and antiphons, motets, arias and church concerti, as well as vernacular songs. Instrumental music consisted of intradas, dances and fanfares. ${ }^{34}$

Music was a vehicle for the acoustic conquest of space, emphasised by an extraordinary iconographic programme. Each group of the procession differed in their garments, and the town space was decorated with paintings, banners, tableaux vivants, and there were declamatory feats and choreographic designs presented by the school boys. Other instruments of religious propaganda included a triumphal arch, built by the town council in honour of Saint Ignatius Loyola, bearing his image and carrying the dedication: "Sancto Patri Ignatio Patriarchae Societatis Jesu - Senatus Populusque Nissensis". The procession passed under this arch on its way to the Collegiate Church of Saint James. ${ }^{35}$

\section{Sacralisation of the town space}

All these events confirmed the orthodoxy of the Jesuit spirituality and reflected the supernatural dimension of the Society's missions. Especially significant were canonisation celebrations; i.e. those of Francis Borgia in 1670, extensively reported in Jesuit Litterae annuae. ${ }^{36}$ The sequence of events took a whole week and involved most of the town's inhabitants. After the liturgy in the collegiate church, they undertook a procession and sung a hymn composed for the occasion. Instrumental music accompanied the choreographic show staged by the convictores in Spanish costumes, there were tableaux vivants illustrating scenes from the saint's life, and a students' gymnastic show, during which the name "Borgia" was formed by a configuration of their bodies. After these spectacles there was a procession, and Iste confessor Domini was performed by the musicians of the collegiate church. On reaching the Jesuit church, they were greeted by the orchestra of the convictus of Saint Anna, which played ex arcu triumphali. The festivities of the day ended with Te Deum, a sermon and vesperae solennes. All the following days abounded in similar events; they differed only as regards the organisers and topography. In this way, during the week, the whole town was filled with music, heard by all of its inhabitants.

33 Songs performed on that occasion were published in the songbook of Jubel- oder Lobgesäng: Denen Heyligen vnd Seeligen der Societet Iesu, welche die Erste Hundert Jahr dieses Ordens in der Kirchen Gottes geleuchtet. In Celebrirung gemeldter Societet JubelFests von der Hochlöblichen Sodalitet B. V. Annunciatae, bey obgenendter Societet zur Neyß auß schuldiger Ehrerbittung vnd Danckbarkeit Dedicirt... Neisse : Johann Schubart, 1640.

34 WITTWER, Max: Die Musikpflege im Jesuitenorden unter besonderer Berücksichtigung der Länder deutscher Zunge. [Inaugural-Dissertation zur Erlangung der Doktorwürde der Hohen Philosophischen Fakultät der Universität Greifswald.] Greifswald : Grimmer Kreis-Zeitung, 1934, pp. 54-55.

35 KROESS, Ref. 17, Vol. III, p. 550.

36 Praha, Národní knihovna, Oddělení rukopisů a starých tisků (hereafter CZ-Pn ORST) XXIII C 105/8: Litterae Annuae Provinciae Bohemiae (1671-1674), fol. 92r-97r. 
Similar festivities accompanied the feasts dedicated to the cult of relics. These events provided excellent opportunities to stimulate new forms of piety, promote the historical traditions of Catholicism and reaffirm its post-Tridentine renewal. The translation of Saint Sisinius relics to the Jesuit church in 1636 was also a topographic event: not only in its universal meaning (thanks to the journey his relics marked while being moved from Rome to Nysa), but also in the local context (the celebration involved representatives of all the churches and monasteries of the town who were invited to this feast). ${ }^{37}$ The martyr's bones were greeted with Vespers musico tubarum vocumque concentu decantatae, after which a new painting depicting the Saint was unveiled in a setting of emblematic pegmata, and a song in his honour was performed by all.

Other festivities were celebrated at the votive columns, often connected with the Marian cult. In 1652, a statue of Notre-Dame-de-Foy was erected in Nysa, patroness against fever and eye diseases. ${ }^{38}$ The statue was a new sacred object in the public urban space, providing a focal point for prayers, singing of litanies, antiphons and vernacular songs appropriate to the occasion, and was the point of departure for processions, replete with music. It was a form of a cult which attracted all sections of the population and involved frequent performances by singers from the local convictus. Their interpretations of the Salve Regina and Ave Maria, for example, became a staple of such paraliturgical celebrations. ${ }^{39}$

\section{Beyond the town walls}

The music also helped conquer the soundscape of the area located outside of the parish space. The word "parishioner" comes from the Greek $\pi \alpha$ ó er". Every Christian in this sense is a "foreigner" in this world (Eph. 2:19), and his destiny is a journey: made not alone, but in the community of Ecclesia peregrinans. So, each pilgrimage is an act of sacralisation of the space which is socialized and appropriated. ${ }^{40}$ The long walk symbolises a fight against oneself, and ultimately to dominate space and to provide a sense of security. ${ }^{41}$

First of all, one has to secure the borders of the community: just as the walls of a city protect against the enemy, so do the sacred figures located at the borders of

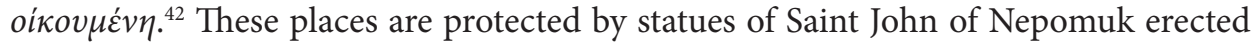
on bridges, of Saint Roch at the crossroads on the edge of the town, and of Holy Virgin Mary on hills. ${ }^{43}$ Each of these statues were destination points of processions led with

37 SCHMIDL, Ref. 12, Vol. IV, pp. 343-344.

38 CZ-Pn ORST XXIII D 147: Historiae collegiorum S. J. Provinciae Bohemiae, fol. 181r.

39 ARSI Boh. 154: Litterae Annuae Provinciae Bohemiae (1736), p. 177.

40 DUPRONT, Alphonse: Il sacro. Crociate e pellegrinaggi, linguaggi e immagini, Torino : Bollati Boringhieri 2006, pp. 33-34.

41 DELUMEAU, Jean: Skrzydła anioła. Poczucie bezpieczeństwa w duchowości człowieka Zachodu w dawnych czasach. Warszawa : Volumen, 1998, p. 140.

42 LE BRAS, Gabriel: La chiesa e il villaggio. Torino : Boringhieri 1979, pp. 69, 72.

43 ARSI Boh. 128: Litterae Annuae Provinciae Bohemiae (1715), p. 143. 
proper music sung in vulgari lingua. ${ }^{44}$ The community walking here and there filled the space with songs; its warps and wefts intertwining in a kind of web of sound.

At the limines of the commune or village, crosses were erected to which the community walked during the processions held on Saint Mark's Day..$^{45}$ They were intended to secure the safety of the community, and there were prayers for a good harvest and protection against drought and epidemics. The variety of plagues and diseases required a rich diversity of intercessors, so the community sang the Litany of the Saints, who were invoked to protect their living area. Silesian Jesuits cultivated and developed traditional forms of folk piety associated with these cults, not only to gain the confidence of the local people, but also to rebuild a Catholic identity.

Pilgrimages to the neighbouring sanctuaries served similar goals. The Jesuits revived the old sacred destinations, and led their sodalities to Bardo, to the Romanesque statue of Madonna and Child. The pilgrimages departed each year on the Feast of the Visitation, and were accompanied by songs and instrumental music. ${ }^{46}$ Over time, they also created new sanctuaries, which stimulated the development of new forms of piety, usually expressed with the appropriate musical performances. The missionaries from Nysa organised pilgrimages to the Chapel of Our Lady in Głogówek ${ }^{47}$ and to the statue of Notre-Dame-de-Foy in Albrechtice, singing the Litany of Loreto ${ }^{48}$ on the way.

\section{The music for conquering space}

It is not an accident that the litany was the musical genre preferred in the discussed circumstances. The recurrence of subsequent invocations alternated with an ora pro nobis response can be seen as an acoustic representation of the community: slowly, but steadily continuing to its destination. The endless repeated prayers correspond to very long journey, which is difficult to imagine at the outset. Even the longest litany is crowned by an Agnus Dei section, just as an all-day penance led to mercy and peace. Among the litanies sung in the Jesuit circles of Nysa, the most frequent was the Litany of the Saints, performed during liturgical mentions of saints: Francis Xavier, ${ }^{49}$ John Francis Regis ${ }^{50}$ and the boarding school's patroness, Saint Anne. ${ }^{51}$ The same text was included in the liturgy of rogation days, when processions were made to the border crossroads, which were sprinkled with holy water. ${ }^{52}$ This custom was intended to ensure a good harvest: ${ }^{53}$ but could be also organised in cases of pest, hunger, fire, and war.

\footnotetext{
ARSI Boh. 95: Litterae Annuae Provinciae Bohemiae (1631-1640), p. 336.

SCHMIDL, Ref. 12, Vol. II, 1749, pp. 586-587.

SCHMIDL, Ref. 12, Vol. III, p. 593.

SCHMIDL, Ref. 12, Vol. IV/2, p. 508.

ARSI Boh. 97 I: Litterae Annuae Provinciae Bohemiae (1651, 1658, 1660), p. 349.

ARSI Boh. 102: Litterae Annuae Provinciae Bohemiae (1679), p. 829.

ARSI Boh. 129: Litterae Annuae Provinciae Bohemiae (1716), pp. 159-160.

ARSI Boh. 126: Litterae Annuae Provinciae Bohemiae (1713), p. 102.

REFF, Daniel T.: Plagues, Priests, and Demons: Sacred Narratives and the Rise of Christianity in the Old World and the New. Cambridge : Cambridge University Press, 2005, p. 100.

53 FASSINO, Gianpaolo: Le processioni delle Rogazioni: dalla fecondità della terra ai confini del villaggio. In: Bollettino dell'Atlante Linguistico Italiano, Vol. 26, 2002, pp. 143-155.
} 
An excellent example of such music is the Litaniae de omnibus Sanctis pro diebus Rogationum composed by Johannes Faber, a Silesian Jesuit, who spent the last years of his life in Nysa working as a confessor and prefect of the citizens' sodality. ${ }^{54}$ One of his obituaries confirms the special devotion of Faber to the saints, which was reflected in his musical output, which included litanies. ${ }^{55}$ A unique extant copy of such a piece comes from the Convent of Canonesses Regular in Wrocław. ${ }^{56}$ Its paraliturgical use is confirmed by a small piece of paper, found inside Violin I partbook with the inscription "ut congruentem pluviam fidelibus tuis concedere digneris". This text is part of a prayer accompanying a procession beseeching for rain, with the formulary De processione ad petendam pluviam. ${ }^{57}$

The architecture of this piece is determined by the structure of the litany's verbal text, ordering successive invocations into groups addressed to angels, apostles, martyrs, doctors of the Church and holy women, followed by various appeals addressed to Christ and closing prayers. The mood of the entire composition is one of intrusive anxiety, calming only in the final Agnus Dei section. Was the prayer heard by Lord? Did He send the showers of rain? If yes, one can say, music composed by our Jesuits has conquered not only the space of the earth, but also of the heavens...

54 JEŻ, Tomasz (ed.): Joannes Faber (1599-1667). Litaniae de omnibus Sanctis pro diebus Rogationum a 10. (= Fontes Musicae in Polonia, C/VII.) Warszawa : Wydawnictwo Naukowe Sub Lupa, 2018.

55 CZ-Pn ORST XXIII C 105/7: Litterae Annuae Provinciae Bohemiae (1665-1669), fol. 348v: “A D. Matre, Coelitibus, S. Ignatio, Angelo Custode, S. Barbara, Catharina, et S. Hedwige, ut tria impetraret in Sacris eoru(m) aliorum(que) nominib(us) concinnatas Litanias ab ipsa Grammatica nunqua $(\mathrm{m}) \mathrm{p}(\mathrm{rae})$ termisit. In votis fuêre, (pri)mo $\mathrm{p}(\mathrm{re})$ serua(ti)o ab impuris cogitationibus. Secundo ut sine supremis $\mathrm{D}$. Mysteriorum $\mathrm{p}$ (rae)sidijs e vita $\mathrm{n}(\mathrm{on})$ discederet; Tertium his iunxit iam religioni Sociat(u)s, ut mors non nisi in Suete abueniret. Et eo quod petit, obtinuit, cum tribus his sibi charissimis libenter in Soc(ieta)te mortu(us)".

56 Today stored in the University Library in Warsaw, RM 6140.

57 Liber Usualis with introduction and rubrics in English, Tournai: Benedictines of Solesmes; New York: Desclee Company. Printers to the Holy See and the Sacred Congregation of Rites 1961, p. 1838. 


\section{Resumé}

\section{HUDBA AKO PROSTRIEDOK NA PODROBENIE SI PRIESTORU V JEZUITSKOM MESTE NYSA}

A OKOLÍ

Prítomnost' jezuitov v umeleckej kultúre raného moderného veku bola definovaná ako misia a prispôsobenie sa „lud’om, dobe a miestu“. Hudba, pokladaná za priestorový fenomén, mala v tejto misii významnú funkciu, zväčša pre svoje rétorické kvality. Na príklade mesta Nisa (Nysa/Neisse) autor štúdie demonštruje, ako hudba zasiahla do spoločenského priestoru miestnej komunity a ovplyvnila jej pocit bezpečia a identity. Opisuje tiež spôsob, akým si hudba podrobila priestor tým, že pretvorila mikrokozmos mesta, ako aj jeho okolia. 